\title{
Eriophyid mites in the genus Aculodes Keifer (Prostigmata: Eriophyidae) from grasses - the first taxon from South America and world species information
}

\section{Vanina Alemandri, Graciela Truol, Renata S. de Mendonça \& Denise Navia}

To cite this article: Vanina Alemandri, Graciela Truol, Renata S. de Mendonça \& Denise Navia (2015) Eriophyid mites in the genus Aculodes Keifer (Prostigmata: Eriophyidae) from grasses - the first taxon from South America and world species information, International Journal of Acarology, 41:5, 429-441, DOI: $10.1080 / 01647954.2015 .1050063$

To link to this article: https://doi.org/10.1080/01647954.2015.1050063

曲 Published online: 17 Jul 2015.

Submit your article to this journal $₫$

LII Article views: 102

View Crossmark data \lceil 


\title{
Eriophyid mites in the genus Aculodes Keifer (Prostigmata: Eriophyidae) from grasses - the first taxon from South America and world species information
}

\author{
Vanina Alemandri ${ }^{\mathrm{a}}$, Graciela Truol ${ }^{\mathrm{a}}$, Renata S. de Mendonça ${ }^{\mathrm{b}}$ and Denise Navia ${ }^{\mathrm{c}}$ \\ ${ }^{a}$ Instituto de Patología Vegetal, Centro de Investigaciones Agropecuarias, Instituto Nacional de Tecnología Agropecuaria (IPAVE-CIAP- \\ INTA),Córdoba, Argentina (emails: alemandri.vanina@inta.gob.ar,truol.graciela@inta.gob.ar); ${ }^{b}$ Fundação de Apoio à Pesquisa \\ (FUNAPE)/Embrapa Recursos Genéticos e Biotecnologia, Parque Estação Biológica, Brasilia, Brazil (email: mendonca.rsm@gmail. \\ com); ${ }^{\circ}$ Embrapa Recursos Genéticos e Biotecnologia, Parque Estação Biológica, Brasilia, Brazil (email: denise.navia@embrapa.br)
}

(Received 25 December 2014; accepted 6 May 2015; published online 17 July 2015)

\begin{abstract}
Aculodes Keifer (Eriophyidae) mites are often associated with grasses (Poaceae) and so far all species in this genus were described from the Northern hemisphere. During surveys of eriophyid mites from grasses conducted in Argentina aiming to determine the host range of the wheat curl mite, a new Aculodes species was collected from the feather grass, Stipa sp. The first Aculodes species is described from the Southern hemisphere. In addition to the traditional morphological description, DNA sequences of two genomic regions - the ITS rDNA and the 16S region mtDNA- were obtained and deposited in public databases; genetic distances of the new taxon with eriophyid species/genera associated with grasses are presented. In order to contribute to Aculodes taxonomy, a list for world grasses-associated species is provided and information on its morphological traits is summarized.
\end{abstract}

Keywords: Eriophyoidea; Poaceae; Argentina; DNA data; taxonomy

\section{Introduction}

The genus Aculodes Keifer, 1966b (Eriophyidae, Phyllocoptinae, Anthocoptini) presently includes 26 species, most of them (21 species) associated with grasses (Poaceae) (Nalepa 1891; Keifer 1944, 1952, 1960, 1966a, 1966b; Sukhareva 1972, 1981, 1985, 1986, 1994; Huang 1992, 2001; Kuang 1997; Kuang and Pang 1997; Shi and Boczek 2000; Skoracka et al. 2001, 2009; Skoracka 2003, 2004, 2005; Kuang et al. 2005; Skoracka and Pacyna 2005; Xue et al. 2010). Until now, all Aculodes species were described from the Northern hemisphere, in Europe, Asia and North America. Only one species in this genus, Aculodes mckenziei (Keifer, 1944), had been reported from the Southern hemisphere, in Australia and New Zealand (Frost et al. 1990; Guy and Gould 1996). No Aculodes species had been described or reported from South America.

Knowledge on eriophyoid mites on grasses in South America is scarce; only eight species belonging to the genera Aceria, Abacarus, Catarhinus, and Schizacea have been described or reported from these plants in the continent (Keifer 1959, 1976, 1977, 1978; Flechtmann and Aranda 1970; Flechtmann 2000; Navia et al. 2006; Pereira et al. 2009; Castiglioni and Navia 2010). In Argentina, only the wheat curl mite, Aceria tosichella Keifer, 1969, had been reported (Navia et al. 2006).

In early 2000s, the wheat curl mite was collected for the first time in South America, in Argentina, from wheat plants infected with Wheat streak mosaic virus (Navia et al., 2006). Since then, surveys of eriophyid mites from grasses in that country have been conducted to determine the host range of the wheat curl mite. From these surveys a new Aculodes species was found from the feather grass Stipa sp. This is the first Aculodes associated with grasses to be described from South America and even from the Southern hemisphere.

Five eriophyoid mites have been described or reported from Stipa grasses - four Eriophyidae species, three in the genus Aceria - A. stipaespinulata Skoracka, 2004 from $S$. joannis Celak and $S$. capillata L. from Poland; $A$. stipaensis Mitrofanov \& Sharonov, 1988 from Stipa sp. from Ukraine (Mitrofanov et al. 1988); and A. stipacea Sukhareva, 1983 described from $S$. lessingiana Trin. et Rupr. from Ukraine and also reported from $S$. capillata in Kazakhstan - and one in the genus Aculodes - A. fulleri (Keifer, 1966a) from S. californica Merr. \& BurttDavy ex Hall. (presently referred as a synonym of $S$. occidentalis Thurb. ex S.Watson (The Plant List 2013)) from California, USA; and one Phytoptidae species, Novophytoptus stipae Keifer, 1962 (host plant Achnatherum speciosum (Trin. \& Rupr.) Barkworth, presently referred as a synonym of Stipa speciosa Trin. \& Rupr. (The Plant List 2013).

DNA-based resources have started to be used in eriophyoid mite systematics about 15 years ago. Important advances have been done using molecular techniques, which had contributed to explore some questions that were difficult to answer some years ago (Navajas and Navia 2010). Cryptic species have been uncovered among eriophyid mites associated with grasses through an integrative approach, including DNA data (Skoracka and Dabert 2010; Skoracka et al. 2012; Miller et al. 2013). Molecular information can help to distinguish species and provide DNA data for new taxa can help to build a 
consistent taxonomy (Dabert et al. 2008). Among molecular markers successfully used for eriophyid mite systematics, we can list the nuclear ribosomal Internal Transcribed Spacer (ITS) and the 16S mitochondrial (Navia et al. 2005; Navajas and Navia 2010; Skoracka et al. 2012; Miller et al. 2013).

In this paper, the description of a new Aculodes mite associated with Stipa grass in Argentina is presented. In addition to the traditional morphological description, including measures and drawings, DNA sequences of two genomic regions - the ITS rDNA and the $16 \mathrm{~S}$ region mtDNA- were obtained and are presented. Genetic distances of the new taxon with eriophyid species/genera were estimated.

Taxonomic literature on Aculodes species associated with grasses is sparse and description of some species is not in English making difficult its access. In a way to contribute to Aculodes taxonomy and make easier new studies, a list for grasses-associated valid species is presented as well as a table with summarized information on its main morphological traits.

\section{Material and methods}

\section{Morphological study}

Mites were collected from leaf samples by direct examination under a dissecting stereomicroscope and directly mounted in modified Berlese medium (Amrine and Manson 1996). Slide-mounted specimens were studied using a research phase and differential interference contrast microscope (Eclipse 80i Nikon, Tokyo, Japan). Relevant structures for taxonomic purposes were measured using a graded eyepiece and illustrated using a camera lucida attached to the miscroscope.

Terminology follows that of Lindquist (1996) and classification is based on Amrine et al. (2003). Measurements are given in micrometers $(\mu \mathrm{m})$ and, unless stated otherwise, refer to the length of the structure. In the description of the female, each measurement of the holotype precedes the corresponding range for the paratypes. Some measurements of paratypes could not be taken because of the position in which the specimens were mounted. The specimen that was drawing in lateral view stayed mounted in a position slightly, since then the ventral seta $e$ was not represented in its drawing. The count of ventral opisthosomal annuli starts from the first full annulus behind the genitalia. Dorsal opisthosomal annuli were counted from the first full annulus behind the middle of the prodorsal shield rear margin. When the length of cheliceral stylets is not given, it means that it was not possible to measure this character, since they were in a bundle that was immersed with other gnathosomal structures. Measurements were conducted according to de Lillo et al. (2010) except for the following: (1) the body length, which was measured from the tip of the frontal lobe to the rear end of the anal lobe, not considering pedipalps; (2) the $s c$ tubercles space measurement (distance between the tubercles), not the $s c$ setae distance; (3) empodium length, which includes its basal portion inserted into the tarsus.

No immature stages were found and only one male was found and studied. Female internal genitalia was not visible in the studied specimens.

Micrographs were obtained using a digital system consisting of the phase and differential interference contrast microscope (Nikon Eclipse 80i, Tokyo, Japan) connected to a digital camera (Nikon DS-Ri, 12.7 mega pixels, Tokyo, Japan) which was in turn connected to a computer with NIS Elements software (Nikon).

Type specimens are deposited as slide-mounted specimens in mite collections at Embrapa Recursos Genéticos e Biotecnologia, Brasilia, Brazil and at Departamento de Entomologia, Fitopatologia e Zoologia Agrícola, Escola Superior de Agricultura "Luiz de Queiroz" (ESALQ), Universidade de São Paulo, Piracicaba, São Paulo, Brazil.

\section{Molecular characterization}

Specimens were preserved in absolute ethyl alcohol and then individualized in an eppendorf tube for DNA extraction.

\section{DNA extraction}

A Chelex method was used to extract DNA from a single mite following Carew et al. (2004). Microcentrifuge tubes containing mites were centrifuged at $20800 \mathrm{~g}$ for $5 \mathrm{~min}$ to ensure that mites were at or near the top of the tube. Three microlitres of Proteinase K (Roche) was added to each tube and mites were crushed using a plastic pestle moulded from a pipette tip (fresh pestle used for each mite extraction). One hundred microlitres of 5\% Chelex (Bio Rad) solution was added per tube, before the tubes were gently vortexed, and incubated, initially for $1-1.5 \mathrm{~h}$ at $55^{\circ} \mathrm{C}$, and then for $8 \mathrm{~min}$ at $90^{\circ} \mathrm{C}$. Mite extractions were cooled on ice and stored at $-20^{\circ} \mathrm{C}$ (Carew et al. 2009).

\section{Polymerase chain reaction amplification (PCR)}

The ITS region (a fragment of about $900 \mathrm{bp}$ ) was amplified using the forward and reverse primers $18 \mathrm{~S}$ and $28 \mathrm{SC}$ as described by Navia et al. (2005). PCR reactions were carried out in a final volume of $25 \mu$ containing $1 \mathrm{U} \mathrm{Taq}$ DNA polymerase (Invitrogen), $2.5 \mathrm{mM} \mathrm{MgCl}_{2}, 0.25 \mathrm{mM}$ dNTP, $0.5 \mu \mathrm{M}$ of each primer, and $6 \mu \mathrm{l}$ of DNA. The reactions were performed with a thermal cycler programmed for one cycle of $4 \mathrm{~min}$ at $94^{\circ} \mathrm{C}$, followed by 35 cycles $\left(30 \mathrm{~s}\right.$ at $94^{\circ} \mathrm{C}, 30 \mathrm{~s}$ at $50^{\circ} \mathrm{C}$, and $1 \mathrm{~min}$ at $72^{\circ} \mathrm{C}$ ) and a final 5 -min extension at $72^{\circ} \mathrm{C}$. The $16 \mathrm{~S}$ region (a fragment of about $400 \mathrm{bp}$ ) was amplified using the forward and reverse primers LR-J-12887 and WCM16S as described by Carew et al. (2009). PCR reactions were carried out in a final volume of $25 \mu$ l containing $0.75 \mathrm{U}$ Taq DNA polymerase (Invitrogen), $2 \mathrm{mM} \mathrm{MgCl}_{2}$, $0.20 \mathrm{mM}$ dNTP, $0.5 \mu \mathrm{M}$ of each primer, and $6 \mu \mathrm{l}$ of 
DNA. The reactions were performed with a thermal cycler programmed for one cycle of $7 \mathrm{~min}$ at $95^{\circ} \mathrm{C}$, followed by 40 cycles $\left(20 \mathrm{~s}\right.$ at $95^{\circ} \mathrm{C}, 45 \mathrm{~s}$ at $53^{\circ} \mathrm{C}$, and $30 \mathrm{~s}$ at $\left.72^{\circ} \mathrm{C}\right)$ and a final 5 -min extension at $72^{\circ} \mathrm{C}$. Amplification products were analysed by $1.5 \%$ agarose gel electrophoresis. The amplified products were purified using QIAquick PCR Purification Kit (QIAGEN, Germany) and sequenced in both directions with the amplification primers using an ABI 3130XL (Applied Biosystems) automated sequencer.

\section{Sequence data}

The genome regions were aligned using progressive multiple-sequence alignment: ClustalX ${ }^{\circledR}$ version 1.81 software (Thompson et al. 1997). All sequences generated in this work were recorded in GenBank (KF648353-KF648356). The ITS and 16S sequences generated here and the corresponding to predominant haplotype $A$. tosichella detected in Argentina published by Skoracka et al. (2012) and Miller et al. (2013) were used to calculate the distances. MEGA6 (Tamura et al. 2013) was used to choose the best substitution model for our data, and for pairwise comparison of genetic distances. Kimura-2-parameter (K2P) and Tamura 3parameter (T92) were chosen as the best model for the ITS and 16S data set, respectively.

\section{Results and discussion}

\section{Taxonomy}

Family Eriophyidae Nalepa, 1898

Subfamily Phyllocoptinae Nalepa, 1892

Tribe Anthocoptini Amrine and Stasny, 1994

Genus Aculodes Keifer, 1966b

Aculodes stipacolus Alemandri and Navia sp. nov. (Figures 1-3)

\section{Differential diagnosis}

The new species was compared to all Aculodes species associated with grasses. Aculodes stipacolus sp. nov. is most similar to $A$. koeleriae Sukhareva, 1985 and to $A$. ponticus Sukhareva, 1986 based on the prodorsal shield ornamentation pattern, with admedian lines complete and subparalell, submedian lines I absent, and submedian lines II following lateral margins of shield. However, it differs from both species in the presence of a prodorsal shield short median line (absent in A. koeleriae and $A$. ponticus); and in the number of empodium rays ( 9 symetrical rays in A. stipacolus, 6-7 in A. ponticus, and 6-7 in $A$. koeleriae). The new species is also similar to $A$. calamaabditus Skoracka, 2003 based on the general aspect of the prodorsal shield - pointed, acuminate slightly curved, and broad-based frontal lobe; complete, subparalell and slightly curved admedian lines; and antero lateral area finely granulated; on the scapular seta ( $s c)$ length - 22 (21-29) in A. stipacolus and 21 (12-28) in
A. calamaabditus - in the overlapped number of dorsal annuli - 71 (64-74) in A. stipacolus and 62 (5979 ) in A. calamaabditus. However, A. stipacolus differs from $A$. calamaabditus in the absence of submedian lines I (present in A. calamaabditus) and in the number of empodium rays ( 9 rays in $A$. stipacolus, 7-8 in A. calamaabditus). The new species share the number of empodium rays (9) with Aculodes bambusae Kuang, 1997 (8-9), Aculodes dubius (Nalepa, 1891), and Aculodes multitricavus Skoracka, 2004 (9).

\section{Description}

Female $(n=10)$. Body wormlike, 191 (191-223), 41 (37-46) wide, whitish.

Gnathosoma: 15 (14-17), projecting slightly downwards; pedipalp coxal seta (ep) 2 (2-2), dorsal pedipalp genual seta $(d)$ simple, 8 (7-9), cheliceral stylets 18 (14-19), oral stylets $14(12-14)$.

Prodorsal shield 37 (36-38), 28 (23-29) wide, subtriangular; frontal lobe pronounced, acuminate, slightly sinuous, relatively broad-based, 6 (6-8), 8 (8-9) wide; smooth. Line pattern of a short median line, faint, on rear $2 / 3$ or $1 / 4$ (longer when seen laterally); admedian line complete, subparalell, slightly curved on rear; submedian lines I absent; submedian lines II following lateral margins of shield; external antero lateral area finely granulated, some granules designing concave or diagonal lines. Scapular tubercles on rear shield margin, 16 (13-16) apart, scapular seta (sc) 22 (21-29), directed backward.

Legs: with all usual segments and setae present. Leg I 29 (28-32); femur 10 (9-10), ventral basifemoral seta (bv) 8 (7-10); genu $6(6-7)$, antaxial genual seta (l”) 15 (15-19); tibia 7 (7-7), paraxial tibial seta $\left(l^{\prime}\right) 8(7-10)$; tarsus 8 (7-8), antaxial fastigial tarsal seta ( $\left.f t^{\prime \prime}\right) 20$ (20-24), paraxial fastigial tarsal seta $\left(f t^{\prime}\right) 12$ (12-16), paraxial unguinal tarsal seta $\left(u^{\prime}\right) 5(5-6)$, tarsal empodium (em) 7 (7-8), simple, bilaterally symmetrical, 9 rays, tarsal solenidion $(\omega) 9(8-10)$, curved, blunt. Leg II 26 (26-29); femur 10 (9-10), ventral basifemoral seta (bv) 10 (10-11); genu 5 (5-6), antaxial genual seta $\left(l^{\prime \prime}\right)$ 8 (7-10); tibia 6 (5-6); tarsus 7 (7-8), antaxial fastigial tarsal seta $\left(f t^{\prime \prime}\right) 18(18-23)$, paraxial fastigial tarsal seta $\left(f t^{\prime}\right) 8(8-9)$, paraxial unguinal tarsal seta $5(5-7)$, tarsal empodium (em) 7 (6-7), simple, bilaterally symmetrical, 8 rays, tarsal solenidion $(\omega) 10(9-10)$, curved, blunt.

Coxigenital region with 5 (5-5) microtuberculated annuli. Coxisternal plates: sternal line (internal coxisternal apodeme) 7 (6-7); coxisternum I and II densely ornamented with numerous curved short lines or dashes. Anterior seta on coxisternum I (1b) 7 (7-10), 10 (9-10) apart; proximal seta on coxisternum I (1a) 13 (12-14), 6 (5-7) apart; proximal seta on coxisternum II (2a) 28 (27-31), 20 (15-20) apart; Female genitalia 13 (11-13), 18 (16-19) 

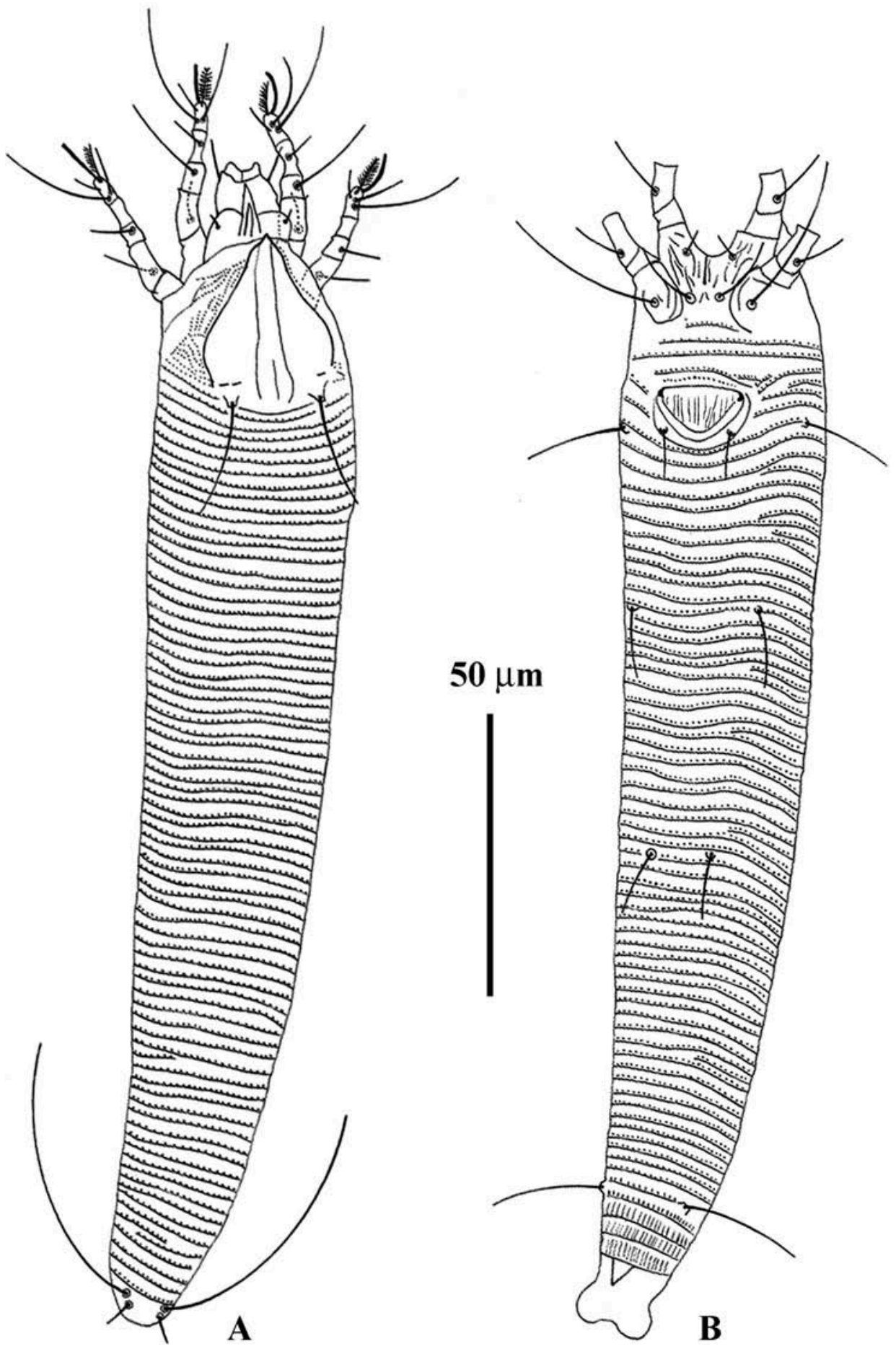

Figure 1. Aculodes stipacolus Alemandri and Navia sp. nov.: (A) dorsal habitus, female; (B) ventral habitus, female.

wide, coverflap with one transverse row of 10 (10-12) longitudinal ridges, genital seta $3 a 12$ (10-19).

Opisthosoma evenly rounded, 71 (64-74) dorsal annuli, 62 (59-67) ventral annuli. Dorsal annuli with minute rounded microtubercles situated on or near rear margin of each annulus; ventral annuli with bead-like microtubercles situated on or near rear margin of each annulus; microtubercles more elongate on the last 5-7 ventral annuli (posteriorly ventral seta $f$ ). Seta $c 221$ (20-27), on ventral annulus 2 (2-2); seta $d 29$ (29-43), on ventral annulus 12 (12-16), 27 (19-27) apart, 20 (18-22) microtubercles apart; seta e $10(10-14)$, on ventral annulus 31 (28-35), $12(10-12)$ apart, 9 (7-10) microtubercles apart; seta $f 18$ (18-26), on ventral annulus 58 (55-63), 16 (8-16) apart, 14 (13-15) microtubercles apart. Caudal seta $h 256(56-85)$, accessory seta $h 1$ 5 (4-6). 


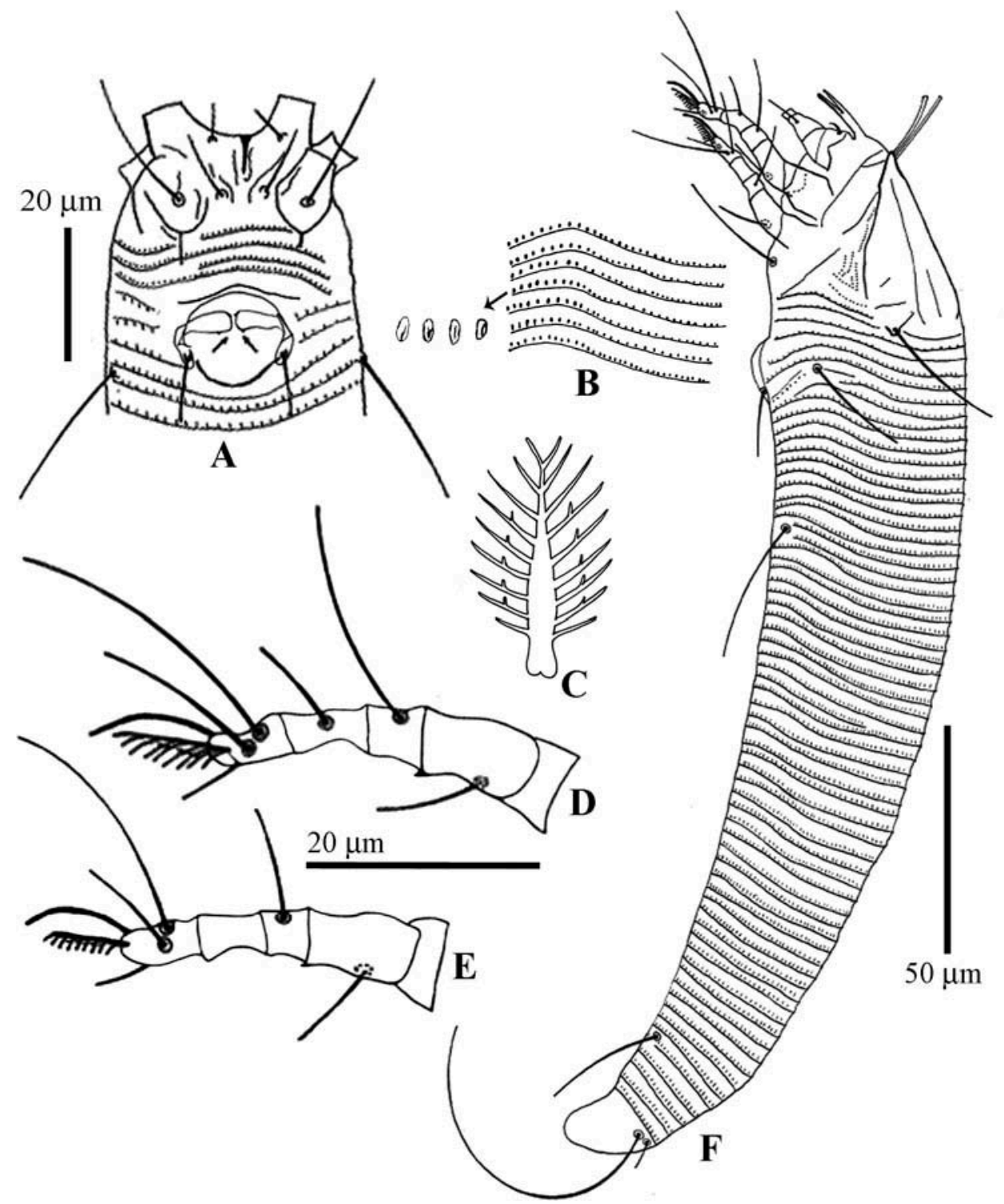

Figure 2. Aculodes stipacolus Alemandri and Navia sp. nov.: (A) coxigenital region, male; (B) detail of microtubercles in lateral view; (C) empodium, female (enlarged); (D) Leg I; (E) Leg 2; (F) Lateral view, female.

Male $(n=1)$ : Smaller than female, 170, 33 wide. Gnathosoma 14; dorsal pedipalp genual seta $(d)$ simple 7 , other setae and structures not clearly distinguishable.

Prodorsal shield 32, 26 wide; frontal lobe and shield design similar to that of the female. Frontal lobe 5, 8 wide. Scapular tubercles on rear margin, 14 apart, scapular seta $(s c)$ 19, directed backward.

Legs with usual series of setae. Leg I 24; femur 9, ventral basifemoral seta $(b v) 6$; genu 7 , antaxial genual seta $\left(l^{\prime \prime}\right)$ 12; tibia 6, paraxial tibial seta $\left(l^{\prime}\right) 6$; tarsus 7 , antaxial fastigial tarsal seta $(e m)\left(f t^{\prime \prime}\right) 18$, paraxial fastigial tarsal seta $\left(f t^{\prime}\right)$ 11, paraxial unguinal tarsal seta $\left(u^{\prime}\right) 5$; tarsal empodium 6 , simple, bilaterally symmetrical, 8 rays, tarsal solenidion ( $\omega$ ) 8, slightly curved, blunt. Leg II 23; femur 9 , ventral basifemoral seta $(b v) 8$; genu 4 , antaxial genual seta $\left(l^{\prime \prime}\right) 8$; tibia 6 ; tarsus 6 , antaxial fastigial tarsal seta $\left(f t^{\prime \prime}\right) 20$, paraxial fastigial tarsal seta $\left(f t^{\prime}\right) 7$, paraxial unguinal tarsal seta $\left(u^{\prime}\right) 5$, tarsal empodium (em) 6, simple, bilaterally symmetrical, 8 rays, tarsal solenidion $(\omega) 9$, slightly curved, blunt.

Coxigenital region with 4 annuli, finely microtuberculated. Coxisternal plates: sternal line (internal coxisternal apodeme) 6; coxisternum I and II with sparse curved short lines or dashes. Anterior seta on coxisternum I (1b) 5, 9 apart; proximal seta on coxisternum I (1a) 10, 5 apart; proximal seta on coxisternum II (2a) 20, 15 apart; male genitalia 12, 16 wide, eugenital seta minute, genital seta $3 a 10$. 

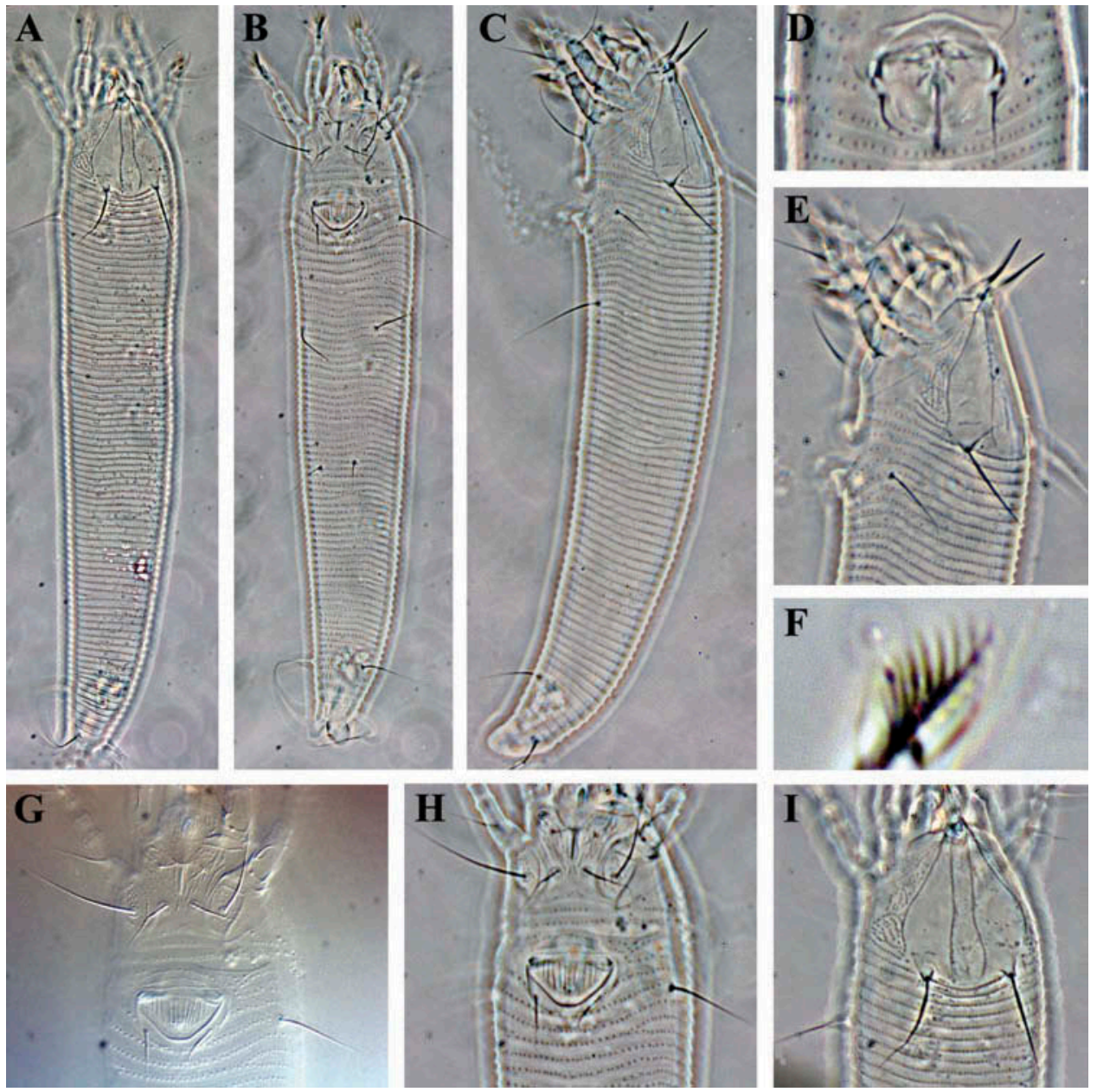

Figure 3. Aculodes stipacolus Alemandri and Navia sp. nov. micrographs. (A) dorsal view, female; (B) ventral view, female; (C) lateral view, female; (D) coxigenital region, male; (E) anterolateral view, female; (F) empodium; (G) coxigenital region, female, under DIC microscope; $(\mathrm{H})$ coxigenital region, female, under phase contrast microscope; (I) anterodorsal view with prodorsal shield ornamentation details.

Opisthosoma evenly rounded, 55 dorsal annuli, 47 ventral annuli. Dorsal and ventral microtubercles similar to that of the female. Seta $c 2$ 20, on ventral annulus 2; seta $d 33$, on ventral annulus 10, 21 apart, 15 microtubercles apart; seta $e$ 6, on ventral annulus 22, 9 apart, 5 microtubercles apart; seta $f 14$, on ventral annulus 43, 13 apart, 13 microtubercles apart. Caudal seta $h 2$ broken, accessory seta $h 13$.

Type material. Holotype female (slide/position 1/1 indicated by a red circle) and fourteen females and one male paratypes, from Stipa sp. (Poaceae), Necochea, Province of Buenos Aires, Argentina ( $\left.38^{\circ} 45.10^{\prime} \mathrm{S}, 58^{\circ} 45.25^{\prime} \mathrm{W}\right)$, 13 January 2012, collected by Mauro Polizzi, on five microscope slides. Holotype and 10 female paratypes on four slides deposited in the mite collection at "Embrapa Recursos Genéticos e Biotecnologia”, Brasília, DF, Brazil. One male and four female paratypes on one slide deposited at "Departamento de Entomologia, Fitopatologia e Zoologia Agrícola, Escola Superior de Agricultura 'Luiz de Queiroz' (ESALQ), Universidade de São Paulo", Piracicaba, São Paulo, Brazil.
Relation to host. All specimens were collected on inner leaf blades, along midrib entire length.

Etymology. The specific designation stipacolus was formed as a composition between stipa that refers to the genus of the host plant, and the New Latin -colus, meaning dwelling in, inhabitting.

\section{Molecular characterization}

Three 16S and three ITS sequences of the Aculodes stipacolus sp. nov. were obtained. One haplotype was identified from $16 \mathrm{~S}$ sequences (GenBank deposit No. KF648353) and three variants were obtained from the ITS sequences (GenBank deposit No. KF648354, KF648355, KF648356). The $16 \mathrm{~S}$ sequence KF134860 of Abacarus hystrix (Nalepa) was incorporated in the distance analysis since it is the unique $16 \mathrm{~S}$ sequence of an eriophyid mite in grasses different to Aceria available in the database. It was not possible to estimate the genetic distance with other mites of the same genus since no 
sequences were available in GenBank. The distance between 16S haplotype of $A$. stipacolus (KF648353) and the predominant $A$. tosichella haplotype detected in Argentina (JQ512769) was 0.2280; and with A. hystrix (KF134860) it was 0.2539. The distance between the three ITS variants of A. stipacolus (KF648354, KF648355, KF648356) and the predominant $A$. tosichella haplotype detected in Argentina (JF960144) were respectively $0.2606,0.2569$, and 0.2587 . These values can be considered as intergeneric distances in the Eriophyidae family.

\section{Aculodes Keifer world species associated with grasses (Poaceae)}

A list of the 21 Aculodes species associated with grasses in the world is presented below. It includes information on type host, type locality, and habitus. Main morphological traits of the grass-associated Aculodes species are presented in Table 1.

\section{Aculodes agropyronis (Keifer, 1960)}

Type host - Agropyron smithi Rydb., presently referred as a synonym of Elymus smithii (Rydb.) Gould (The Plant List 2013).

Type locality - Texas, USA.

Habitus - In young rolled leaves and on leaf plate near sheath.

\section{Aculodes bambusae Kuang, 1997}

Type host - Bambusa sp.

Type locality - Hangzhou City, Zhejiang Province, China. Habitus - Vagrant.

\section{Aculodes calamaabditus Skoracka, 2003}

Type host - Calamagrostis epigeios (L.) Roth., presently the accepted name is Calamagrostis epigejos (L.) Roth (The Plant List 2013).

Type locality - Path in Forest, Lesna Dolina $\left(16^{\circ} 12^{\prime} \mathrm{E}, 51^{\circ}\right.$ $\left.44^{\prime} \mathrm{N}\right)$, Glogow, Poland.

Habitus - Vagrants on upper leaf surface, often hiding in furrows.

\section{Aculodes capillarisi Skoracka, 2003}

Type host - Agrostis capillaris L.

Type locality - Forest path, Biedrusko near Poznan $\left(16^{\circ}\right.$ $\left.55^{\prime} \mathrm{E}, 52^{\circ} 29^{\prime} \mathrm{N}\right)$, Poland.

Habitus - Vagrants on upper leaf surface, mostly near the top.

\section{Aculodes deschampsiae (Sukhareva, 1972)}

Type host - Deschampsia cespitosa (L.) P. Beauv. Type locality - Park of the Biological Institute, Leningrad University in old Petergof, Leningrad Region, Russia. Habitus - Vagrant in grooves on upper leaf surface. References - Drawings and taxonomic characterization also in Skoracka (2004).

\section{Aculodes dubius (Nalepa, 1891)}

Type host - Helictotrichon pratense (L.) Besser ex Pilg. Type locality - Austria? (in Amrine and Stasny 1994).

Habitus - In grooves between veins on surface of leaves; greening of flowers.

Reference - Drawings and taxonomic characterization also in Skoracka (2004).

\section{Aculodes festucae Skoracka, Labrzycka and Rector, 2009}

Type host - Festuca arundinaceae Schreb.

Type locality - Gorski Kotar mountains, around $30 \mathrm{Km}$ $\mathrm{NE}$ of Rijeka $\left(14^{\circ} 35.047^{\prime} \mathrm{E}, 45^{\circ} 28.848^{\prime} \mathrm{N}\right)$, Croatia.

Habitus - Vagrants on upper leaf surface.

\section{Aculodes fulleri (Keifer, 1966a)}

Type host - Stipa californica Merr. \& Burtt-Davy ex Hall., presently referred as a synonym of Stipa occidentalis Thurb. ex S.Watson (The Plant List 2013).

Type locality - Upper King's Creek, Lassen Nat. Pk., Shasta Co., California, USA.

Habitus - The mites live in rib grooves on upper leaf surfaces.

\section{Aculodes holcusi Skoracka, 2004}

Type host - Holcus mollis L.

Type locality - Mountain meadow with southern exposure, Przechyba, Beskid Sadecki Mts., Poland.

Habitus - Vagrant on upper leaf surfaces.

\section{Aculodes janboczeki Skoracka, 2005}

Original description -Type host - Bromus inermis Leyss. Type locality - Meadow near Oak Forest $\left(48^{\circ} 02.730^{\prime} \mathrm{N}\right.$, $\left.20^{\circ} 28.814^{\prime} \mathrm{E}\right), 580 \mathrm{~m}$ above sea level, Bukki Mts., Hungary.

Habitus - Vagrants on upper leaf surfaces.

\section{Aculodes koeleriae Sukhareva, 1985}

Type host - Koeleria cristata (L.)., presently referred as a synonym of Koeleria pyramidata (Lam.) P.Beauv. (The Plant List 2013).

Type locality - In steppe-like meadow, vicinity of Putsilovska, Pogranichnyy Distr., Maritime Territory, Primorskiy Kraj, Russia.

Habitus - Vagrant on upper leaf surface; on strips between veins on upper surfaces of leaves.

\section{Aculodes kransnovi Sukhareva, 1994}

Type host - Sasa palmata E. G. Camus. Type locality - Batumskoy Botanical Garden, Georgia. Habitus - Mites were found on the surface of the leaves, in the gaps between the ridges.

\section{Aculodes levis Huang, 2001}

Type host - Phyllostachys makinoi Hayata. Type locality - Kaohsiung, Tengchih, Taiwan, China. 


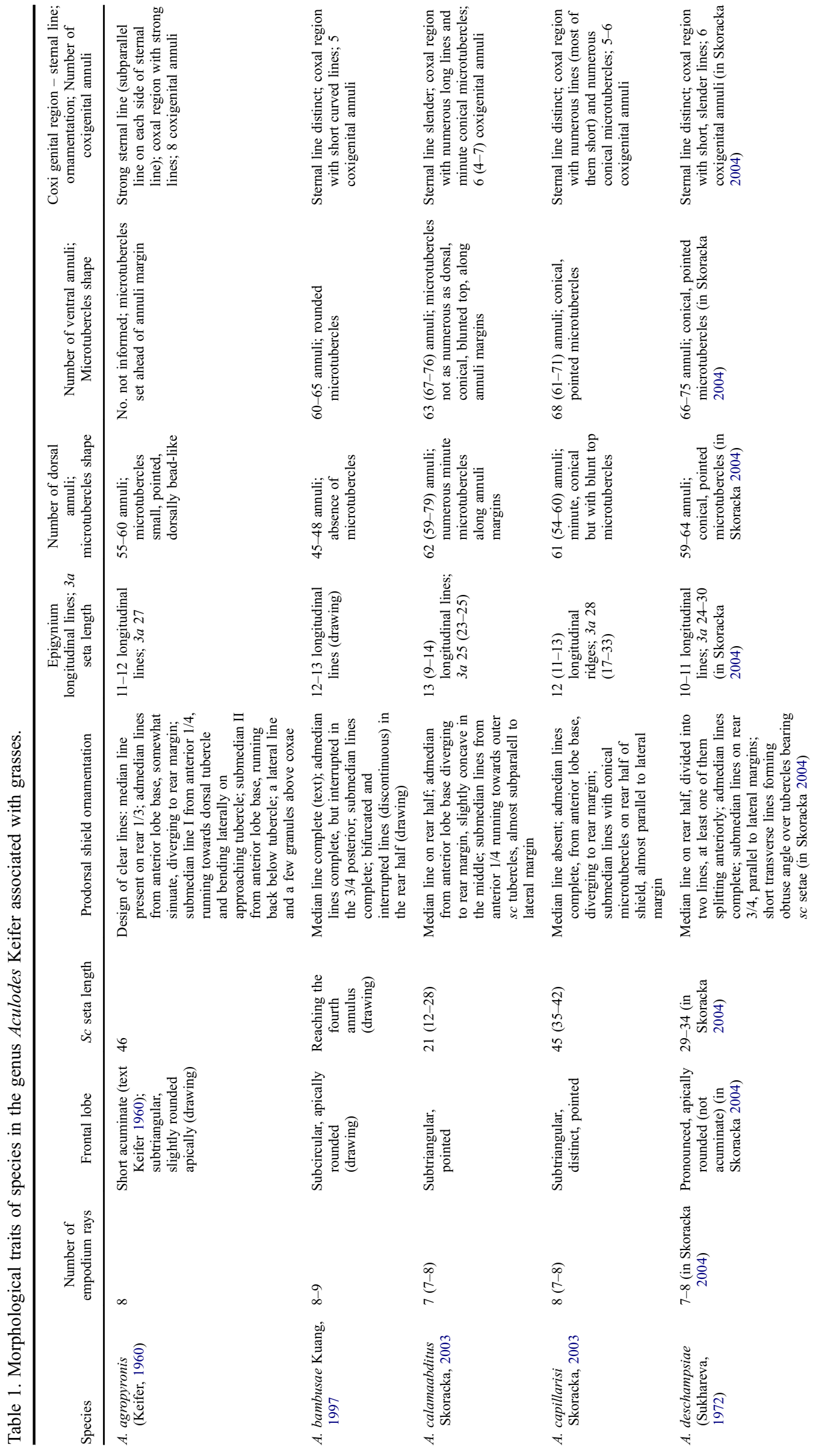



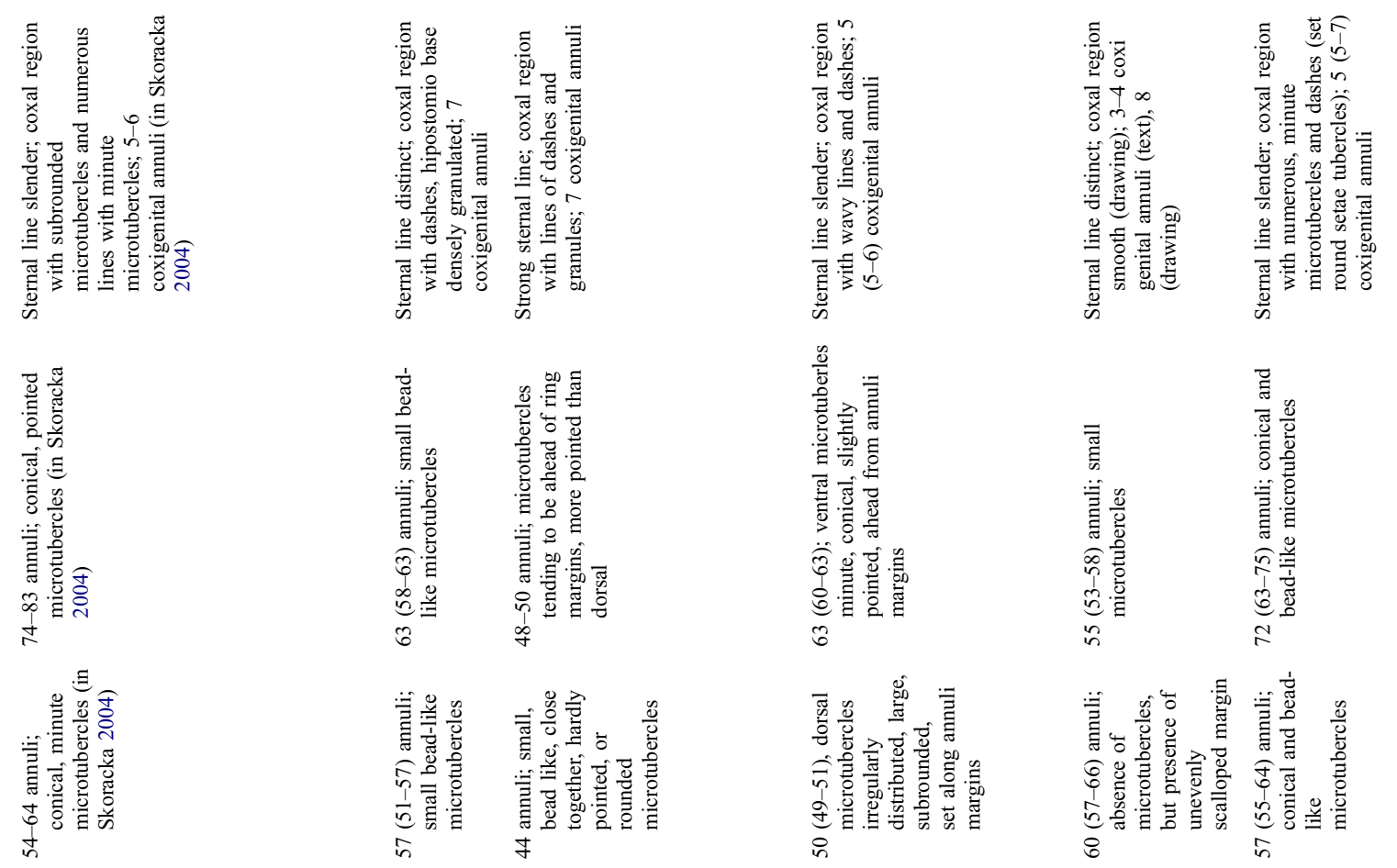

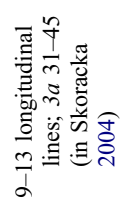
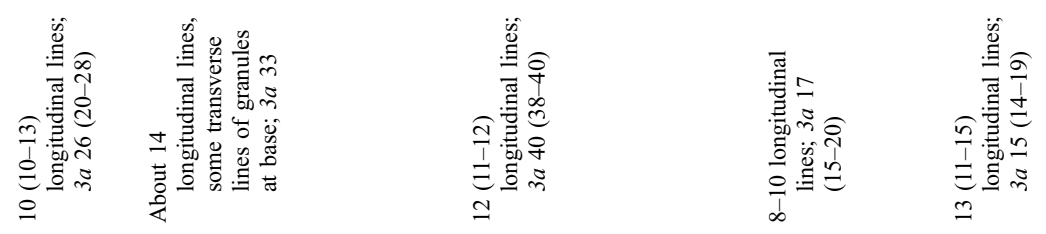

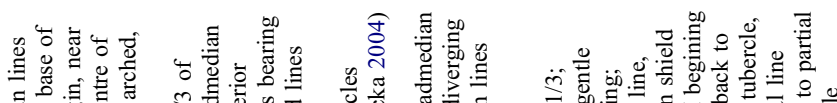

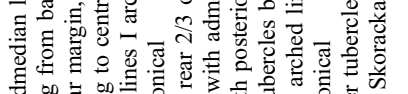

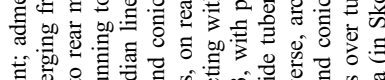

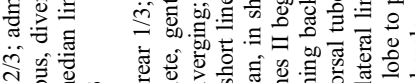

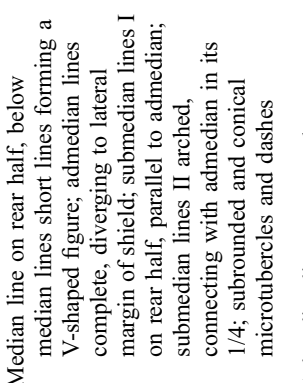

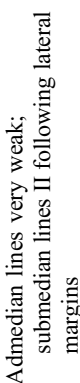

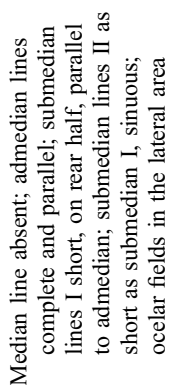

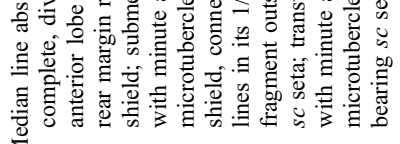

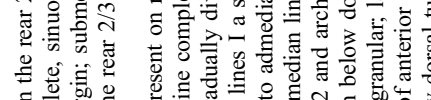

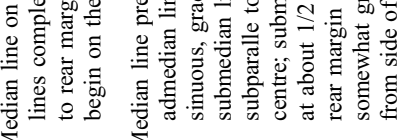

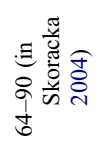

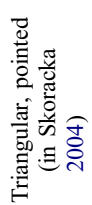

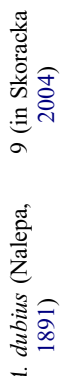

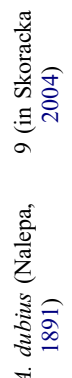

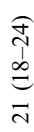

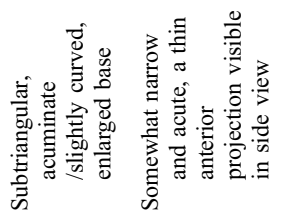

$\widehat{6}$
$\infty$
0
0
0

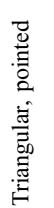

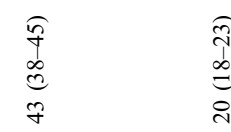

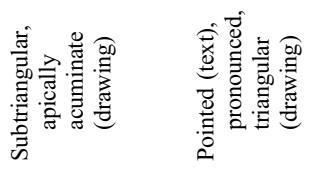

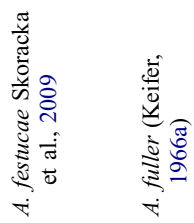

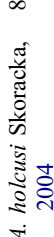

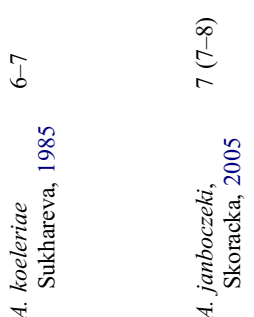




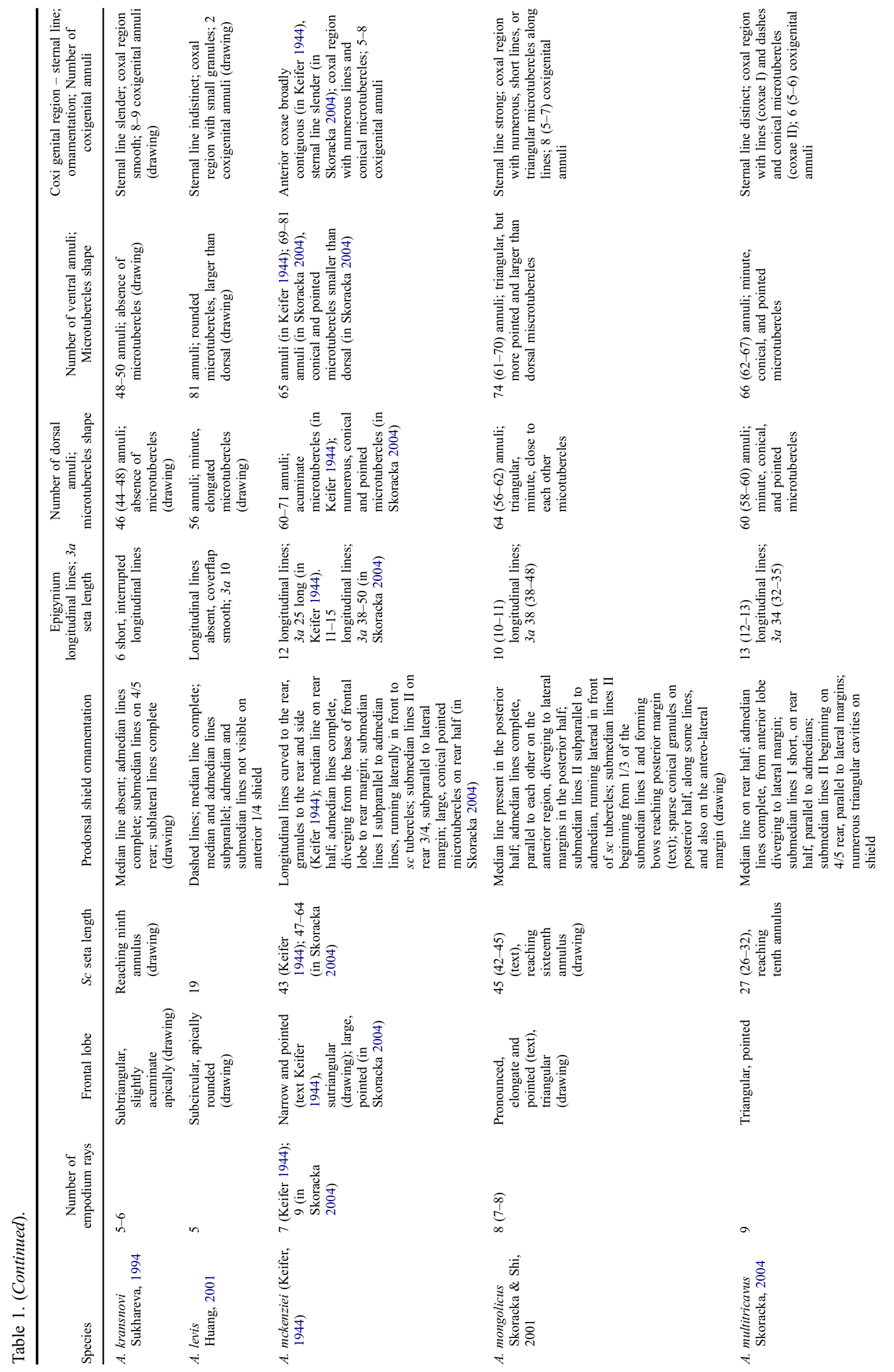



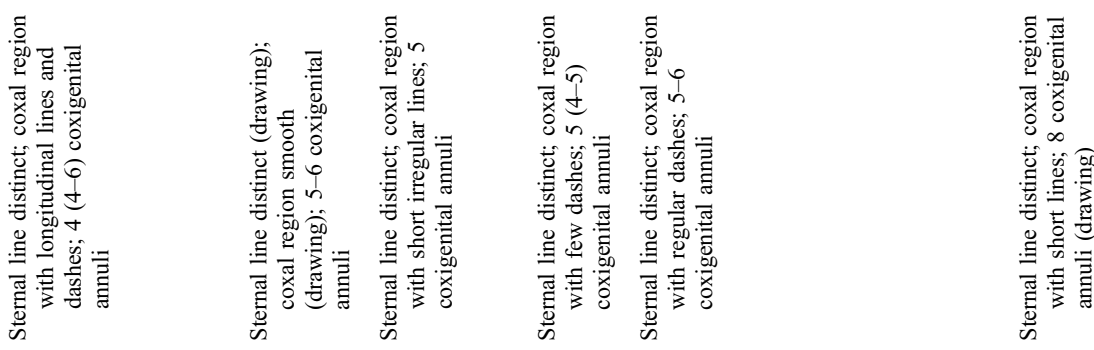

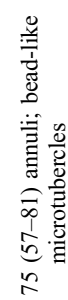
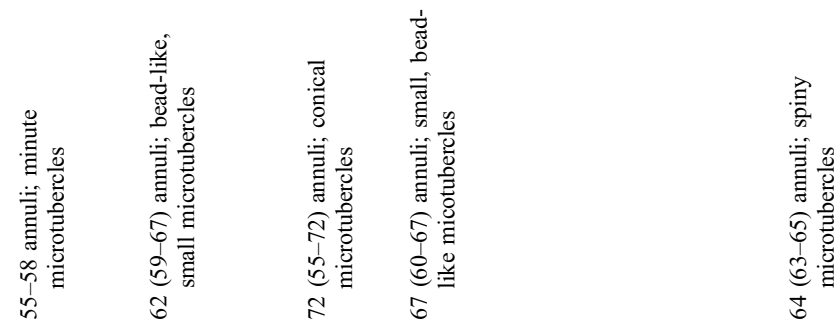

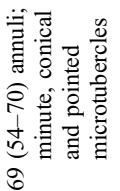
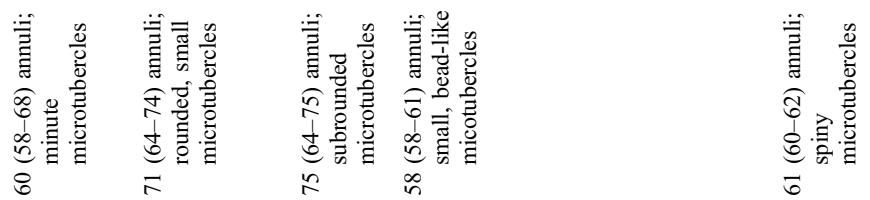

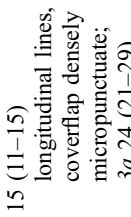

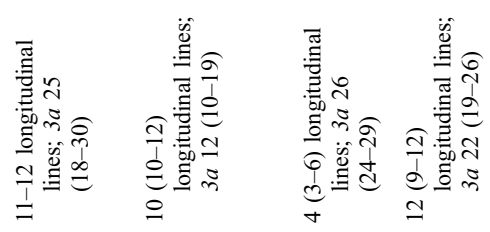

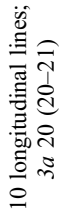

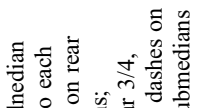

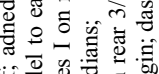

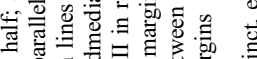

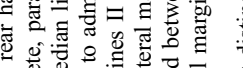

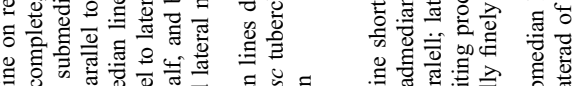

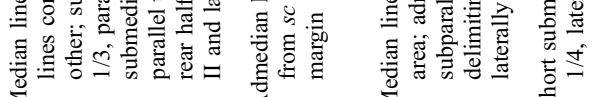

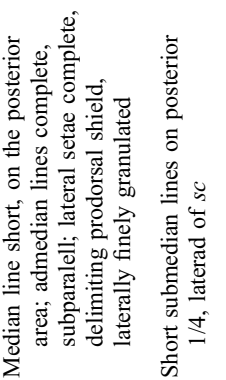

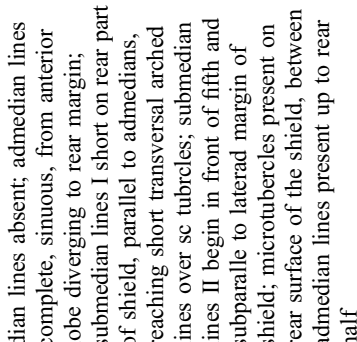

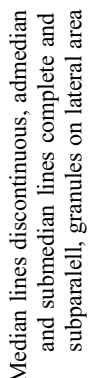

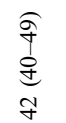

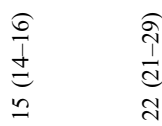

$\begin{array}{ll}\text { สิ } & \text { d } \\ 0 & \text { d } \\ \text { in } & 0 \\ \text { in } & 0\end{array}$

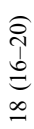

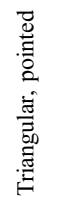

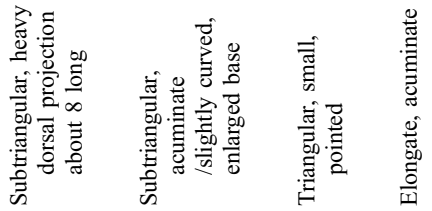
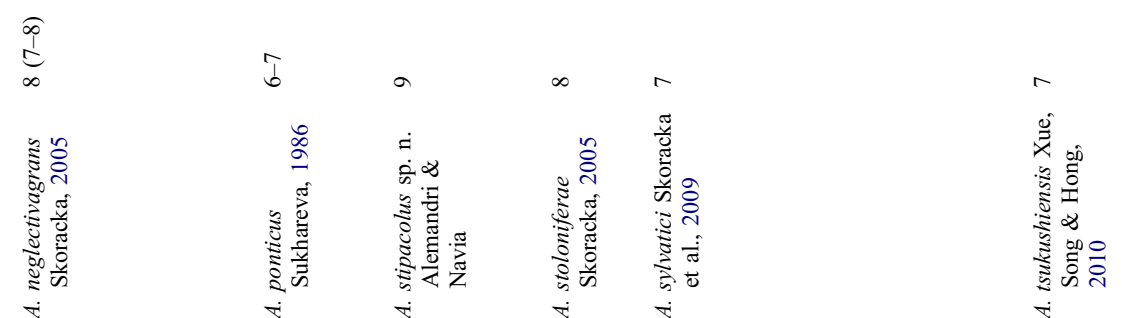
Habitus - Vagrant on lower leaf surface. No damage observed.

\section{Aculodes mckenziei (Keifer, 1944)}

Type host - Leymus triticoides (Buckl.) Pilg. Type locality - Sacramento, California, USA.

Habitus - The mites occur in upper surface, leaf furrows. They cause some browning.

Reference - Drawings and taxonomic characterization also in Skoracka (2004).

Obs - Sukhareva (1981) considered two subspecies for this taxon, A. mckenziei subsp. brevisetus and A. mckenziei subsp. trivialis.

\section{Aculodes mongolicus Skoracka \& Shi, 2001}

Type host - Hordeum brevisubulatum (Trin.) Link. Type locality - Arkhangy Aymag, Horgo Terhiyn Tsagaan Nuur National Park, Central Mongolia.

Habitus - Mites are vagrants on upper leaf surface.

Aculodes multitricavus Skoracka, 2004

Type host - Bromus inermis Leyss.

Type locality - Xerothermic sward, Owczary, Poland.

Habitus - Vagrant on upper leaf surfaces.

\section{Aculodes neglectivagrans Skoracka, 2005}

Type host - Calamagrostis neglecta (Ehrh.) Gaertn., Mey et Schreb., presently referred as a synonym of Calamagrostis stricta (Timm) Koeler (The Plant List 2013).

Type locality - Littoral dune, $14 \mathrm{~m}$ elev., $10 \mathrm{~km} \mathrm{~W}$ of Kuzrjeka Village, near Turij Cape, S. of Umba, White Sea Coast, Kola Peninsula, Russia. $\left(66^{\circ} 35.722^{\prime} \mathrm{N}, 34^{\circ}\right.$ 42.965' E)

Habitus - Vagrants on upper leaf surfaces.

Reference - Skoracka and Pacyna (2005).

\section{Aculodes ponticus Sukhareva, 1986}

Type host - Eremopyrum distans (Koch) Nevski. Type locality - Near Kabardinka Village, Krasnodarski Kraj, Russia.

Habitus - Deep grooves between veins on surface of the leaves.

\section{Aculodes stoloniferae Skoracka, 2005}

Type host - Agrostis stolonifera L. subsp. straminea (Hartm.) Tzvel.

Type locality - Taiga, near a stony beach, near Turij Cape, S. of Umba, White Sea. Coast, $\left(66^{\circ} 37.822^{\prime}\right.$ N, $34^{\circ} 27.345^{\prime}$

E) Kola Peninsula, Russia.

Habitus - Vagrants on upper leaf surfaces.

Reference - Skoracka and Pacyna (2005).

Aculodes sylvatici Skoracka, Labrzycka and Rector, 2009

Type host - Brachypodium sylvaticum (Huds.) P. Beauv.
Type locality - Velebit mountains, around $24 \mathrm{Km} \mathrm{SE}$ of Senj $\left(15^{\circ} 02.830^{\prime} \mathrm{E}, 44^{\circ} 56.412^{\prime} \mathrm{N}\right)$, Croatia.

Habitus - Vagrants on upper leaf surface.

\section{Aculodes tsukushiensis Xue, Song, Hong, 2010}

Type host - Elymus tsukushiensis Honda var. transiens (Hack.) Osad.

Type locality - Zhouzhi County, Shaanxi Province, P.R. elevation $500 \mathrm{~m},\left(34^{\circ} 03^{\prime} 54^{\prime \prime} \mathrm{N}, 108^{\circ} 19^{\prime} 22^{\prime \prime} \mathrm{E}\right)$, China.

Habitus - Vagrant on leaf surfaces. No damage to the host was observed.

\section{Acknowledgements}

Authors DN and RSM are grateful to National Council for Scientific and Technological Development (CNPq), Brazil, for research and pos-doc fellowships, respectively. Thanks also to Dr. Philipp E. Chetverikov, Saint-Petersburg State University, Russia, for traduction of Sukhareva's papers from Russian to English and to Mr. Mauro Polizzi for sample collection and host plant identification in Argentina.

\section{Funding}

This work was supported by the Embrapa [Macroprograma 2 Call 22/2011 -Embrapa/INTA]

\section{References}

Amrine Jr, JW, Manson DCM. 1996. Preparation, mounting and descriptive study of Eriophyoid mites. In: Lindquist EE, Sabelis MW, Bruin J, editors. Eriophyoid mites: their biology, natural enemies and control. Amsterdam: Elsevier, World Crop Pests; p. 383-396. n. 6.

Amrine Jr, JW, Stasny TA. 1994. Catalog of Eriophyoidea (Acari: Prostigmata) of the world. West Bloomfield (MI): Indira Publishing House.

Amrine Jr, JW, Stasny TAH, Flechtmann CHW. 2003. Revised keys to the world genera of the Eriophyoidea (Acari: Prostigmata). West Bloomfield (MI): Indira Publishing House.

Carew M, Schiffer M, Umina P, Weeks A, Hoffmann A. 2009. Molecular markers indicate that the wheat curl mite, Aceria tosichella Keifer, may represent a species complex in Australia. Bulletin of Entomological Research 99:479-486.

Carew ME, Goodisman MAD, Hoffmann AA. 2004. Species status and population genetic structure of grapevine eriophyoid mites. Entomologia Experimentalis et Applicata 111:87-96.

Castiglioni E, Navia D. 2010. Presence of the Wheat Curl Mite, Aceria tosichella Keifer (Prostigmata: Eriophyidae), in Uruguay. Agrociencia 14:19-26.

Dabert J, Ehrnsberger R, Dabert M. 2008. Glaucalges tytonis sp. n. (Analgoidea, Xolalgidae) from the barn owl Tyto alba (Strigiformes, Tytonidae): compiling morphology with DNA barcode data for taxon descriptions in mites (Acari). Zootaxa 1719:41-52.

de Lillo E, Craemer C, Amrine Jr, JW, Nuzzaci G. 2010. Recommended procedures and techniques for morphological studies of Eriophyoidea (Acari: Prostigmata). Experimental and Applied Acarology 51:283-307.

Flechtmann CHW. 2000. Two new species of Aceria (Acari: Eriophyidae) on grass from Brazil. International Journal of Acarology 26:335-338.

Flechtmann CHW, Aranda BRC. 1970. New records and notes on Eriophyid mites from Brazil and Paraguay, with a list of 
Eriophyidae from South America. Proceedings of the Entomological Society of Washington 72:94-98.

Frost WE, Eagling DR, Manson DCM. 1990. Abacarus hystrix (Nalepa) (Acarina: Eriophyidae) newly recorded in Australia. Australian Journal of Entomology 29:182.

Guy PL, Gould DM. 1996. Aculodes mckenziei (Acari: Eriophyidae) newly recorded in New Zealand and its association with other eriophyids in South Island pastures. New Zealand Entomologist 19:61-64.

Huang KW. 1992. Some new eriophyoid mites from Taiwan (Acari: Eriophyoidea). Bulletin of the National Museum of Nature and Science 3:227-228.

Huang KW. 2001. The eriophyid mites of Taiwan: description of eighty-six species from the Tengchih Area. Bulletin of the National Museum of Nature and Science 14:1-84.

Keifer HH. 1944. Eriophyid Studies XIV. Bulletin of the California Department of Agriculture 33:18-38.

Keifer HH. 1952. The eriophyid mites of California. Bulletin of the California Insect Survey 2:1-123.

Keifer HH. 1959. Eriophyid studies XXVII. Bulletin of the California Department of Agriculture.

Keifer HH. 1960. Eriophyid studies B-1. Sacramento (CA): California Department of Agriculture.

Keifer HH. 1962. Eriophyid studies B-8. Sacramento (CA): California Department of Agriculture.

Keifer HH. 1966a. Eriophyid studies B-20. Sacramento (CA): California Department of Agriculture.

Keifer HH. 1966b. Eriophyid studies B-21. Sacramento (CA): California Department of Agriculture.

Keifer HH. 1976. Eriophyid studies C-12. Sacramento (CA): California Department of Agriculture.

Keifer HH. 1977. Eriophyid studies C-13. Sacramento (CA): California Department of Agriculture.

Keifer HH. 1978. Eriophyid studies C-15. Sacramento (CA): California Department of Agriculture.

Kuang H, Pang H. 1997. Four new species of the Eriophyinae (Acari: Eriophyidae) from China. Entomotaxonomia 19:232233.

Kuang HY. 1997. Four new species of Eriophyidae (Acari: Eriophyoidea) from China. Entomotaxonomia 19:74-78.

Kuang HY, Luo GH, Wang AW. 2005. Fauna of Eriophyid mites from China (II) (Acari: Eriophyoidea). Beijing: China Forestry Publishing House.

Lindquist EE. 1996. External anatomy and notation of structures. In: Lindquist EE, Sabelis MW, Bruin J, editors. Eriophyoid mites: their biology, natural enemies and control. Amsterdam: Elsevier, World Crop Pests; p. 3-31. n. 6.

Miller AD, Skoracka A, Navia D, Mendonça RS, Szydło W, Schultz MB, Smith C, Truol G, Hoffmann AA. 2013. Phylogenetic analyses reveal extensive cryptic speciation and host specialization in an economically important mite taxon. Molecular Phylogenetics and Evolution 66:928-940.

Mitrofanov VI, Sharonov AA, Badulin AV. 1988. New species of mites of the genus Aceria (Acariformes, Eriophyoidea). Zoologicheskii Zhurnal 67:790-794.

Nalepa A. 1891. Genera und Species der Familie Phytoptida. Denkschriften, Akademie der Wissenschaften in Wien, Mathematisch-Naturwissenschaftliche Klasse 58:867-884.

Navajas M, Navia D. 2010. DNA-based methods for eriophyoid mite studies: review, critical aspects, prospects and challenges. Experimental and Applied Acarology 51:257-271.

Navia D, Moraes GJ, Roderick G, Navajas M. 2005. The invasive coconut mite Aceria guerreronis (Acari: Eriophyidae): origin and invasion sources inferred from mitochondrial (16S) and nuclear (ITS) sequences. Bulletin of Entomological Research 95:505-516.

Navia D, Truol G, Mendonça RS, Sagadín M. 2006. Aceria tosichella Keifer (Acari: Eriophyidae) from Wheat Streak
Mosaic Virus-infected wheat plants in Argentina. International Journal of Acarology 32:189-193.

Pereira PRVS, Navia D, Salvadori JR, Lau D. 2009. Occurrence of Aceria tosichella in Brazil. Pesquisa Agropecuária Brasileira 44:539-542.

The Plant List (2013). Version 1.1. [Internet]. [cited 2015 Mar 10]. Available from: http://www.theplantlist.org/

Shi A, Boczek J. 2000. Studies on eriophyoid mites (Acari: Eriophyoidea). XXXIX. Bulletin of the Polish Academy of Sciences 48:323-327.

Skoracka A. 2003. New species of Aculodes (Acari: Eriophyoidea) from grasses in Poland. Acta Zoologica Academiae Scientiarum Hungaricae 49:43-60.

Skoracka A. 2004. Eriophyid mites from grasses in Poland (Acari: Eriophyoidea). Genus 13:1-205.

Skoracka A. 2005. Two new species and four new records of eriophyoid mites from grasses in Hungary (Acari: Eriophyoidea). Genus 16:445-462.

Skoracka A, Dabert M. 2010. The cereal rust mite Abacarus hystrix (Acari: Eriophyoidea) is a complex of species: evidence from mitochondrial and nuclear DNA sequences. Bulletin of Entomological Research 100:263-272.

Skoracka A, Kuczynski L, Mendonça RS, Dabert M, Szydło W, Knihinicki D, Truol G, Navia D. 2012. Cryptic species within the wheat curl mite Aceria tosichella (Keifer) (Acari, Eriophyoidea) revealed by mitochondrial, nuclear and morphometric data. Invertebrate Systematics 26:417-433.

Skoracka A, Labrzycka A, Rector BG. 2009. Three new species of eriophyoid mites (Acari: Prostigmata: Eriophyoidea) from grass hosts in Croatia. Annals of the Entomological Society of America 102:12-19.

Skoracka A, Pacyna A. 2005. Grass associated eriophyoid mites (Acari: Eriophyoidea) from the Kola Peninsula, Russia. Annales Zoologici 55:453-466.

Skoracka A, Shi AX, Pacyna A. 2001. New eriophyoid mites (Acari: Eriophyoidea) associated with grasses from Mongolia. Zootaxa 9:1-18.

Sukhareva SI. 1972. New species of quadrupedal mites of the genus Phytocoptes (Acarina, Eriophyoidea). Zoologichesky Zhurnal 51:296-299.

Sukhareva SI. 1981. O strukture chetireh naibolee rasprostranenih vidov chetirenogih klescej (Acarina: Tetrapodili) so zlakov: Aceria tritici Shev., Aculodes mckenziei (K), Aculodes dubius (Nal.), Abacarus hystrix (Nal.). The structure of the 4 most distributed eriophyid mites (Acarina: Tetrapodili) from grasses, etc. Vestnik Leningradskogo Universiteta 15:25-36.

Sukhareva SI. 1983. New species of Eriophyid mites of the genus Aceria Keifer. (Acariformes, Tetrapodili) living on grasses. Entomologicheskoe Obozrenie 62:391-396.

Sukhareva SI. 1985. New species of mites (Acarina: Tetrapodili) on grasses from Primorskij Kraj. (Maritime Territory). Entomologicheskoe Obozrenie 64:227-234.

Sukhareva SI. 1986. New species of eriophyid mites (Acariformes: Tetrapodili) living on grasses in the SSSR. Entomologicheskoe Obozrenie 65:850-855.

Sukhareva SI. 1994. The four-legged mites (Acariformes: Tetrapodili) on the bamboos in Georgia. Vestnik SanktPetersburgkogo Universiteta, Seriya 3, Biologiya 1:33-38.

Tamura K, Stecher G, Peterson D, Filipski A, Kumar S. 2013. MEGA6: molecular evolutionary genetics analysis version 6.0. Molecular Biology and Evolution 30:2725-2729.

Thompson JD, Gibson TJ, Plewniak F, Jeanmougin F, Higgins DG. 1997. The CLUSTALX windows interface: flexible strategies for multiple sequence alignment aided by quality analysis tools. Nucleic Acids Research 25:4876-4882.

Xue XF, Song ZW, Hong XY. 2010. Five new species of Anthocoptini from China (Acari: Eriophyidae). Zootaxa 2666:29-44. 